\title{
The Role of New Viral Biomarkers in Chronic Hepatitis B: Ready to Use in the Clinical Practice?
}

Kronik Hepatit B'de Yeni Viral Göstergelerin Rolü: Klinik Uygulamada Kullanıma Hazır mı?

\author{
(D) Suna YAPALI \\ Acıbadem University Faculty of Medicine, Department of Gastroenterology, Istanbul, Turkey
}

\begin{abstract}
Recent advances have been made to develop and improve the serologic and molecular virologic tools for the diagnosis and optimal management of chronic hepatitis B (CHB) infection. Several biomarkers associated with the natural course of chronic hepatitis $B$ infection virus (HBV) and the efficacy of antiviral treatment have been defined. This article reviews the impact of hepatitis $B$ surface antigen, hepatitis B core-related antigen and HBV RNA on the natural history, treatment response and outcomes of $\mathrm{CHB}$ infection. Keywords: Hepatitis B surface antigen, hepatitis B core-related antigen, hepatitis $B$ virus RNA
\end{abstract}

\section{$\ddot{0 Z Z}$}

Son yıllarda kronik hepatit B (KHB) enfeksiyonunun tanısı ve optimal yönetimi için serolojik ve moleküler virolojik araçlar geliştirilmiştir. Kronik hepatit $B$ virüsünün (HBV) doğal seyri ve antiviral tedavinin etkinliği ile ilişkili birçok viral gösterge tanımlanmıştır. Bu makalede, hepatit B yüzey antijeni, hepatit B kor-ilişkili antijen ve HBV RNA'nın KHB enfeksiyonunun doğal seyri, tedavi cevabı ve sonuçları üzerine etkisi derlenmiştir.

Anahtar Kelimeler: Hepatit B yüzey antijeni, hepatit B kor-ilişkili antijen, hepatit $B$ virus RNA

Yapalı S. The Role of New Viral Biomarkers in Chronic Hepatitis B: Ready to Use in the Clinical Practice? Viral Hepat J. 2018;24:57-60.

\section{Introduction}

Chronic hepatitis B (CHB) infection affects over 350 million people in the world and it is responsible for more than 500.000 deaths annually (1). Cirrhosis and hepatocellular carcinoma (HCC) are the major complications of $\mathrm{CHB}$ infection. With the availability of potent antiviral agents, management of $\mathrm{CHB}$ patients improved. However, it is still difficult to predict the risk of liver disease progression and the risk of $\mathrm{HCC}$ in $\mathrm{CHB}$ infection. Furthermore, the clearance of covalently closed circular DNA (cccDNA) from the host genome and eradication of the virus cannot be achieved with the current treatments. The treatment recommendations of the professional liver societies are mainly based on the clinical status, serum hepatitis B virus (HBV) DNA, alanine aminotransferase (ALT) level, hepatitis $\mathrm{B}$ e antigen ( $\mathrm{HBeAg}$ ) status and liver histology (if available). High serum HBV DNA level is an independent predictor of $\mathrm{HCC}$ and an important determinant for the decision of treatment (2). With the recent advances in the molecular investigations, the role of new biomarkers in the natural history and during the treatment of $\mathrm{CHB}$ has been increasingly recognized. This article reviews the role of new biomarkers during the natural course and treatment of $\mathrm{CHB}$ infection, with a special emphasis on hepatitis B surface antigen ( $\mathrm{HBsAg}$ ) and hepatitis B core-related antigen (HBcrAg) levels and HBV-RNA quantification.

\section{Hepatitis B Surface Antigen Quantification}

Qualitative HBsAg is an important marker in the detection of HBV infection. The majority of HBsAg is secreted by subviral particles and to a lesser extent by infectious virions (3). HBsAg reflects the content of intrahepatic HBV DNA, cccDNA transcription and host immune response to HBV infection $(4,5)$ The kinetics of 
HBsAg production are complex and show significant differences during the natural course of $\mathrm{CHB}$ and between HBV-genotypes. There is strong correlation of HBsAg with HBV replication only in the early phases of infection. The association between HBsAg and HBV DNA has been reported to be more prominent in HBVgenotype $\mathrm{D}$, compared to HBV-genotype A. HBsAg levels were found to be related to HBV-reactivation in low viremic HBeAgnegative carriers (6). In a retrospective 8-year follow-up of HBeAgnegative CHB patients, HBsAg levels $<100 \mathrm{lU} / \mathrm{mL}$ and HBV DNA $<2.000 \mathrm{IU} / \mathrm{mL}$ were found to predict the inactive phase with a high chance of HBsAg loss. CHB patients with a HBV DNA level of 2.000-5.000 IU/mL who have an annual decline of HBsAg $\geq 0.5 \mathrm{log}$ $\mathrm{IU} / \mathrm{mL}$ have also been reported to have a high probability to become inactive carriers. HBsAg level has a good performance in identifying the phases of $\mathrm{CHB}$ during the natural course of the infection and can be helpful in determining the follow-up periods (7).

Serum HBsAg level correlates well with the cccDNA and intrahepatic HBV DNA and a is a strong predictor of response to pegylated-interferon (Peg-IFN) in HBeAg-positive patients. A reduction in HBsAg levels shows the induction of immune control. HBsAg level has been found to predict good response to Peg-IFN and lamivudine treatment better than HBV DNA (8). HBsAg level is an important predictor of response to PegIFN- $\alpha$, however there may be genotypic differences $(9,10)$. Quantification of HBsAg in HBeAg-positive patients may help in decision making regarding individualized treatment. In HBeAgpositive CHB patients, an HBsAg level of $<1.500 \mathrm{IU} / \mathrm{mL}$ at week 12 predicts a high probability $\mathrm{HBeAg}$ seroconversion, while an HBsAg level of $>20.000 \mathrm{IU} / \mathrm{mL}$ for HBV genotype B and C or no decline in HBsAg levels for HBV genotype $A$ and $D$ are associated with a very low rate of $\mathrm{HBeAg}$ seroconversion $(9,10)$. The European Association for the Study of the Liver (EASL) recommends considering specific stopping rules according to HBsAg levels at week 12 of Peg-IFN treatment (11). In HBeAgnegative $\mathrm{CHB}$ patients, early serum HBsAg decline was found to be associated with sustained virological response in patients receiving Peg-IFN- $\alpha$ treatment (12). The combination of lack of decrease in HBsAg level and $<2 \log \mathrm{IU} / \mathrm{mL}$ decline at the $12^{\text {th }}$ week of Peg-IFN treatment has $100 \%$ negative predictive value for treatment response and discontinuation of treatment is recommended by the EASL guideline (10).

Compared to Peg-IFN treatment, HBsAg decline during nucleoside/tide analogs (NA) therapy is much slower. The immune modulation by IFN results in a more rapid HBsAg decline. On the other hand, NAs inhibit only the reverse transcription of the pregenomic RNA but do not target the cccDNA directly and have a less pronounced effect on HBsAg secretory pathways $(13,14)$. Furthermore, integrated HBV DNA in HBeAg-negative patients leads to production of $\mathrm{HBsAg}$.

HBsAg levels in HBeAg-negative patients may be helpful to predict in which patient treatment can be stopped. A study by Hadziyannis et al. (15) showed that discontinuation of antiviral therapy led to sustained off-treatment HBV DNA suppression in $55 \%$ of patients and subsequent HBsAg loss in $39 \%$ of $\mathrm{HBeAg}$ negative $\mathrm{CHB}$ patients who received adefovir treatment for $4-5$ years. Lower HBsAg levels at the end of treatment were predictive for later HBsAg loss.
In a systematic review of 22 studies, an HBsAg level of $<100$ or $<200 \mathrm{IU} / \mathrm{mL}$ at the end of therapy has been suggested to be a good indicator of sustained response (16). HBsAg levels have promising evidence for predicting in which patients treatment can be stopped, however, more data are needed to confirm the thresholds for discontinuation of treatment.

\section{Hepatitis B Virus Core-related Antigen}

$\mathrm{HBcrAg}$ is a novel biomarker of $\mathrm{CHB}$ infection, which measures serum levels of HBcAg, HBeAg and the empty particle (p22) (17). Quantification of HBcrAg is first developed in Japan by comparing the chemiluminescence signals generated by known concentration of recombinant pro-HBeAg (18). This assay (Fujirebio, Tokyo, Japan) is currently available with a lower limit of detection of $2.0 \mathrm{log} \mathrm{U} / \mathrm{mL}$, and a linear range of $3.0 \log \mathrm{U} / \mathrm{mL}-7.0 \mathrm{log} \mathrm{U} / \mathrm{mL}$.

Serum HBcrAg level was found to correlate with serum HBV DNA, intrahepatic DNA and cccDNA levels (17). HBcrAg levels may show variation during the natural course of $\mathrm{CHB}$ infection. Studies in the European and Asian cohorts showed that $\mathrm{HBcrAg}$ levels were higher in $\mathrm{HBeAg}$-positive $\mathrm{CHB}$ patients in comparison to HBeAg-negative patients $(19,20)$. In an Asian cohort, it was found that HBcrAg levels were $8.54 \log \mathrm{U} / \mathrm{mL}$, and $7.92 \log \mathrm{U} / \mathrm{mL}$ in the immune tolerant phase and in the immune clearance phase, respectively. Lower HBcrAg levels suggested a better immune control in $\mathrm{HBeAg-positive} \mathrm{patients.} \mathrm{Among} \mathrm{HBeAg}$-negative patients, HBcrAg levels were $2.60 \mathrm{log} \mathrm{U} / \mathrm{mL}$, and $4.92 \mathrm{log} \mathrm{U} / \mathrm{mL}$ in inactive carriers and $\mathrm{CHB}$ patients, respectively. $\mathrm{HBcrAg}$ levels in HBeAg-negative patients with $\mathrm{CHB}$ showed a positive correlation with necroinflammatory activity and fibrosis (19). After HBsAg seroclearance, HBcrAg levels were found to be undetectable in $79 \%$ of patients, while $21 \%$ had median HBcrAg 2.7 log U/mL (19). HBcrAg levels were found to be associated with development of HCC in both treated and untreated patients $(21,22)$. In a large cohort of $1031 \mathrm{CHB}$ patients with a median 10-year follow-up, HBcrAg > $2.9 \log U / \mathrm{mL}$ (HR, 5.05; 95\% confidence interval, 2.4010.63) was associated with an increased incidence of HCC (22).

HBcrAg may have an important role in predicting the clinical outcomes in patients on treatment. In their study, Wong et al. (23) reported that HBcrAg was detected in 101 (78\%) of 130 samples with undetectable HBV DNA collected from NA-treated patients and there was a positive correlation between $\mathrm{HBcrAg}$ and cccDNA. As HBV DNA is undetectable in the majority of patients on treatment, $\mathrm{HBcrAg}$ levels may be considered as an indirect marker of cccDNA. The decline in HBcrAg has been found to be slower than in HBV DNA levels during NA treatment (24). The rationale is; NAs inhibit HBV DNA replication by the action on the reverse transcription but without elimination of cccDNA from the infected hepatocyte. In some Asian studies, the decline of HBcrAg was found to correlate with the decline of intrahepatic cccDNA in patients receiving entecavir treatment $(23,25,26)$.

In a study of 46 patients treated with Peg-IFN, a baseline HBcrAg level of $>8$ log $U / \mathrm{mL}$ was reported to have low probability of $\mathrm{HBeAg}$ seroconversion ( $>94.4 \%$ negative predictive value) and suppression of HBV DNA at 12 weeks (27). Furthermore, changes in $\mathrm{HBcrAg}$ levels may be helpful in predicting clinical outcomes during treatment. In a study of $58 \mathrm{HBeAg}$-positive $\mathrm{CHB}$ patients treated with Peg-IFN, the HBcrAg at week 12 of therapy was 
found to be predictive of $\mathrm{HBeAg}$ seroconversion at 24 weeks after completion of therapy (28).

The role of HBcrAg for predicting HBsAg loss was examined in a study of $62 \mathrm{HBeAg}$-negative $\mathrm{CHB}$ patients receiving Peg-IFN alone or in combination with tenofovir, the chance of HBsAg loss was higher in patients with baseline $\mathrm{HBcrAg}<3.7 \log \mathrm{U} / \mathrm{mL}$ (29).

The majority of $\mathrm{HBeAg}$-negative $\mathrm{CHB}$ patients remain on treatment until HBsAg loss is achieved. There are many attempts to determine the predictors of relapse after discontinuation of treatment. The decision for discontinuation of treatment can be determined by viral serological markers, serum HBV DNA, ALT and more recently, HBsAg levels. HBcrAg levels may provide prognostic information for the decision of treatment discontinuation. In studies performed in Japan, a high end-oftreatment HBcrAg level was shown to predict relapse after discontinuation of NA therapy $(30,31,32,33)$. In a study of 113 patients receiving NA treatment (lamivudin: 32, entecavir: 81), end-of-treatment $\mathrm{HBcrAg}$ level $>3.7 \mathrm{log} \mathrm{IU} / \mathrm{mL}$ predicted virological relapse within 1 year of NA discontinuation (33). The Japanese Society of Hepatology guidelines have recently recommended the use of an HBsAg level of $<1.9 \log \mathrm{U} / \mathrm{mL}$ and an HBcrAg level of $<3.0 \log \mathrm{U} / \mathrm{mL}$ to identify patients at low risk of relapse (34). However, there is a need to examine the performance of these criteria in different populations.

Recently, HBcrAg positivity has been found to be a significant risk factor for HBV reactivation in HBsAg-negative, anti-HBCpositive patients undergoing high-risk immunosuppressive therapy (especially rituximab-containing chemotherapy), and to have potential to identify patients who would most benefit from prophylactic antiviral treatment (35).

The use of HBcrAg will most probably lead to progress in the management of $\mathrm{CHB}$. However, most of the studies are performed in Japan and Asian countries, and these data need to be confirmed in the Western populations.

\section{Hepatitis B Virus RNA Quantification}

During HBV replication, pregenomic RNAs are encapsidated into HBV core particles in the cytoplasm, and all pregenomic RNAs are reverse transcribed into plus stranded genomic DNA in the core particle (36). HBV RNA has also been detected in the serum of $\mathrm{CHB}$ patients and found to strongly correlate with HBV DNA levels (36). Studies have reported decreased HBV RNA levels in patients receiving NA and the combination of Peg-IFN and NA $(37,38)$. The decrease in HBV RNA levels was predictive for $\mathrm{HBeAg}$ seroconversion suggesting a better role of HBV RNA \pm HBV DNA for treatment monitoring $(37,38)$.

\section{Conclusion}

HBsAg, HBcrAg and HBV RNA quantification provides new perspectives in understanding HBV virology and immunopathogenesis. The implementation of HBsAg quantification has already been integrated into European treatment guidelines. The use of HBcrAg seems to be in the pipeline, however, the results need to be validated in other populations with different ethnic and genotypic characteristics. There is a growing body of evidence for the impact of HBV RNA in patients receiving treatment. In future, the use of new biomarkers may guide the clinicians to predict the natural course, treatment response and the outcome of $\mathrm{CHB}$, adapting individualized treatment approaches.

\section{Ethics}

Peer-review: Internally peer-reviewed.

Financial Disclosure: The author declared that this study received no financial support.

\section{References}

1. GBD 2013 Mortality and Causes of Death Collaborators: Global, regional, and national age-sex specific all-cause and cause-specific mortality for 240 causes of death, 1990-2013: a systematic analysis for the Global Burden of Disease Study 2013. Lancet. 2015; 385(9963): 117-71.

2. Chen CJ, Yang HI, Su J, Jen CL, You SL, Lu SN, Huang GT, lloeje $\mathrm{UH}$. Risk of hepatocellular carcinoma across a biological gradient of serum hepatitis B virus DNA level. JAMA. 2006;4;295:65-73.

3. Op den Brouw $M L$, Binda $R S$, van Roosmalen $M H$, Protzer $U$, Janssen HL, van der Molen RG, Woltman AM. Hepatitis B virus surface antigen impairs myeloid dendritic cell function: a possible immune escape mechanism of hepatitis B virus. Immunology. 2009;126: 280-89.

4. Chan HL, Thompson A, Martinot-Peignoux $M$, Piratvisuth $T$, Cornberg $\mathrm{M}$, Brunetto MR, Tillmann $\mathrm{HL}$, Kao JH, Jia JD, Wedemeyer H, Locarnini S, Janssen HL, Marcellin P.Hepatitis B surface antigen quantification: why and how to use it in 2011 - a core group report. J Hepatol. 2011;55:1121-1131.

5. Su TH1, Hsu CS, Chen CL, Liu CH, Huang YW, Tseng TC, Liu CJ, Chen PJ, Lai MY, Chen DS, Kao JH. Serum hepatitis B surface antigen concentration correlates with HBV DNA level in patients with chronic hepatitis B. Antivir Ther. 2010;15:1133-39.

6. Jaroszewicz J, Serrano BC, Wursthorn K, Deterding K, Schule $J$, Raupach R, Flisiak R, Bock CT, Manns MP, Wedemeyer $H$, Cornberg M. Hepatitis B surface antigen (HBsAg) levels in the natural history of hepatitis B virus (HBV)-infection: A European perspective. J of Hepatol. 2010, 52:514-22.

7. Brouwer WP, Chan HL, Brunetto MR, Martinot-Peignoux $M$, Arends $\mathrm{P}$, Cornberg $\mathrm{M}$, Cherubini $\mathrm{B}$, Thompson AJ, Liaw YF, Marcellin $P$, Janssen $H L$, Hansen BE; Good Practice in using HBsAg in Chronic Hepatitis B Study Group (GPs-CHB Study Group). Repeated Measurements of Hepatitis B Surface Antigen Identify Carriers of Inactive HBV During Long-term Follow-up. Clin Gastroenterol Hepatol. 2016;14(10):1481-1489.

8. Chan HL, Wong VW, Tse AM, Tse $\mathrm{CH}$, Chim AM, Chan HY, Wong GL, Sung JJ. Serum Hepatitis B Surface Antigen Quantitation Can Reflect Hepatitis B Virus in the Liver and Predict Treatment Response. Clin Gastroenterol Hepatol. 2007;5(12):1462-8.

9. Sonneveld MJ, Hansen BE, Piratvisuth T, Jia JD, Zeuzem S, Gane E, Liaw YF, Xie Q, Heathcote EJ, Chan HL, Janssen HL. Responseguided peginterferon therapy in hepatitis $B$ e antigen-positive chronic hepatitis B using serum hepatitis B surface antigen levels. Hepatology. 2013;58:872-880.

10. Brunetto MR, Marcellin P, Cherubini B, Yurdaydin C, Farci $P$, Hadziyannis SJ, Rothe $V$, Regep L, Bonino F. Response to peginterferon alfa-2a (40KD) in HBeAg-negative CHB: on-treatment kinetics of HBsAg serum levels vary by HBV genotype. J Hepatol. 2013;59:1153-1159.

11. European Association for the Study of the Liver. EASL 2017 Clinical Practice Guidelines on the management of hepatitis B virus infection.J Hepatol. 2017;67(2):370-398.

12. Moucari R, Mackiewicz V, Lada O, Ripault MP, Castelnau C, Martinot-Peignoux M, Dauvergne A, Asselah T, Boyer N, Bedossa P, Valla D, Vidaud M, Nicolas-Chanoine MH, Marcellin P. Early 
serum HBsAg drop: a strong predictor of sustained virological response to pegylated interferon alfa-2a in $\mathrm{HBeAg}$-negative patients. Hepatology. 2009;49(4):1151-7.

13. Manesis EK, Hadziyannis ES, Angelopoulou OP, Hadziyannis SJ. Prediction of treatment-related HBsAg loss in HBeAG-negative chronic hepatitis B: a clue from serum HBsAg levels. Antivir Ther. 2007:12:73-82.

14. Reijnders JG, Rijckborst $V$, Sonneveld MJ, Scherbeijn SM, Boucher CA, Hansen BE, Janssen HL. Kinetics of hepatitis B surface antigen differ between treatment with peginterferon and entecavir. J Hepatol. 2011;54:449-454.

15. Hadziyannis SJ, Sevastianos V, Rapti I, Vassilopoulos D, Hadziyannis E. Sustained responses and loss of $\mathrm{HBsAg}$ in $\mathrm{HBeAg}$-negative patients with chronic hepatitis B who stop long-term treatment with adefovir. Gastroenterology. 2012;143:629-636.

16. Chang ML, Liaw YF, Hadziyannis SJ. Systematic review: cessation of long-term nucleos(t)ide analogue therapy in patients with hepatitis B e antigen-negative chronic hepatitis B. Aliment Pharmacol Ther. 2015;42:243-257.

17. Wong DK, Tanaka Y, Lai CL, Mizokami M, Fung J, Yuen MF. Hepatitis $B$ virus core-related antigens as marker for monitoring chronic hepatitis B infection. J Clin Microbiol. 2007; 45:3942-7.

18. Mak LY, Wong $D K H$, Cheung $K S$, Seto $D K$, Lai $C L$, Yuen MF. Hepatitis B core-related antigen ( $\mathrm{HBcrAg}$ ): an emerging marker for chronic hepatitis B infection. Aliment Pharmacol Ther . 2017; 1-12.

19. Seto WK, Wong DK, Fung J, Huang FY, Liu KS, Lai CL, Yuen MF. Linearized hepatitis $B$ surface antigen and hepatitis $B$ core-related antigen in the natural history of chronic hepatitis B. Clin Microbiol Infect. 2014;20:1173-1180.

20. Maasoumy B, Wiegand SB, Jaroszewicz J, Bremer B, Lehmann P, Deterding K, Taranta A, Manns MP, Wedemeyer H, Glebe D, Cornberg M. Hepatitis B core- related antigen (HBcrAg) levels in the natural history of hepatitis $B$ virus infection in a large European cohort predominantly infected with genotypes A and D. Clin Microbiol Infect. 2015;21:606 e1-606 e10.

21. Honda M, Shirasaki T, Terashima T, Kawaguchi K, Nakamura M, Oishi N, Wang X, Shimakami T, Okada H, Arai K, Yamashita T, Sakai Y, Yamashita T, Mizukoshi E, Kaneko S. Hepatitis B Virus (HBV) core-related antigen during nucleos(t)ide analog therapy is related to intrahepatic HBV replication and development of hepatocellular carcinoma. J Infect Dis. 2016;213:1096-106.

22. Tada T, Kumada T, Toyoda H, Kiriyama S, Tanikawa M, Hisanaga Y, Kanamori A, Kitabatake S, Yama T, Tanaka J. HBcrAg predicts hepatocellular carcinoma development: An analysis using time-dependent receiver operating characteristics. J Hepatol. 2016:65:48-56.

23. Wong DK, Seto WK, Cheung KS, Chong CK, Huang FY, Fung J, Lai CL, Yuen MF. Hepatitis B virus core-related antigen as a surrogate marker for covalently closed circular DNA. Liver Int. 2017;37:995-1001.

24. Rokuhara A, Tanaka E, Matsumoto A, Kimura T, Yamaura T, Orii K, Sun X, Yagi S, Maki N, Kiyosawa K. Clinical evaluation of a new enzyme immunoassay for hepatitis B virus core-related antigen; a marker distinct from viral DNA for monitoring lamivudine treatment. J Viral Hepat. 2003;10:324-330.

25. Lam YF, Seto WK, Fung J, Lai CL, Yuen MF Continuous entecavir for treatment naive chinese chronic hepatitis $B$ patients in the real world setting the seven year results. Hepatol Int. 2015;9:S204.

26. Wong DK, Tanaka Y, Lai CL, Mizokami M, Fung J, Yuen MF. Hepatitis $B$ virus core-related antigens as markers for monitoring chronic hepatitis B infection. J Clin Microbiol. 2007;45:3942-3947.
27. Chuaypen N, Posuwan N, Payungporn S, Tanaka Y, Shinkai N, Poovorawan Y, Tangkijvanich P. Serum hepatitis B core-related antigen as a treatment predictor of pegylated interferon in patients with $\mathrm{HBeAg-positive} \mathrm{chronic} \mathrm{hepatitis} \mathrm{B.} \mathrm{Liver} \mathrm{Int.}$ 2016;36:827-836.

28. Ma H, Yang RF, Li XH, Jin Q, Wei L. HBcrAg identifies patients failing to achieve $\mathrm{HBeAg}$ seroconversion treated with pegylated interferon Alfa-2b. Chin Med J. 2016;129:2212-2219.

29. Martinot-Peignoux M, Lapalus M, Boyer N, Castelnau C, Giuily $\mathrm{N}$, Pouteau M. The baseline combination of HBcrAg and $\mathrm{HBsAg}$ titers enhance treatment outcome and HBsAg loss predictions in $\mathrm{HBeAg}$ negative chronic hepatitis $\mathrm{B}$ patients treated with pegylated interferon alfa-2a or PeglFN plus Tenofovir-disoproxilfumarate. Hepatology. 2015;62:1205A.

30. Matsumoto A, Tanaka E, Minami M, Okanoue T, Yatsuhashi $H_{\text {, }}$ Nagaoka S, Suzuki F, Kobayashi M, Chayama K, Imamura M, Yotsuyanagi H, Nakaoka S, Maki N, Kawata S, Kumada H, lino S, Kiyosawa K. Low serum level of hepatitis B core-related antigen indicates unlikely reactivation of hepatitis after cessation of lamivudine therapy. Hepatol Res. 2007;37:661-666.

31. Okuhara $\mathrm{S}$, Umemura $T$, Joshita $\mathrm{S}$, Shibata $\mathrm{S}$, Kimura $T$, Morita S, Komatsu M, Matsumoto A, Yoshizawa K, Katsuyama Y, Ota M, Tanaka E. Serum levels of interleukin- 22 and hepatitis B core-related antigen are associated with treatment response to entecavir therapy in chronic hepatitis B. Hepatol Res. 2014;44:E172-E180.

32. Shinkai N, Tanaka $Y$, Orito $E$, Ito $K$, Ohno T, Hirashima N, Hasegawa I, Sugauchi F, Ueda R, Mizokami M. Measurement of hepatitis B virus core-related antigen as predicting factor for relapse after cessation of lamivudine therapy for chronic hepatitis B virus infection. Hepatol Res. 2006;36:272-276.

33. Jung KS, Park JY, Chon YE, Kim HS, Kang W, Kim BK, Kim SU, Kim do Y, Han KH, Ahn SH. Clinical outcomes and predictors for relapse after cessation of oral antiviral treatment in chronic hepatitis B patients. J Gastroenterol. 2016;51:830-839.

34. Drafting Committee for Hepatitis Management G, the Japan Society of H. JSH Guidelines for the Management of Hepatitis B Virus Infection. Hepatol Res. 2014;44:1-58.

35. Seto WK, Wong DK, Chan TS, Hwang YY, Fung J, Liu KS, Gill $\mathrm{H}$, Lam YF, Cheung KS, Lie AK, Lai CL, Kwong YL, Yuen MF. Association of hepatitis $\mathrm{B}$ core- related antigen with hepatitis $B$ virus reactivation in occult viral carriers undergoing high-risk immunosuppressive therapy. Am J Gastroenterol. 2016;111:17881795.

36. Su Q, Wang SF, Chang TE, Breitkreutz R, Hennig H, Takegoshi K, Edler L, Schröder CH. Circulating hepatitis B virus nucleic acids in chronic infection: representation of differently polyadenylated viral transcripts during progression to nonreplicative stages. Clin Cancer Res. 2001; 7: 2005-2015.

37. Jansen $L$, Kootstra NA, van Dort KA, Takkenberg RB, Reesink HW, Zaaijer HL. Hepatitis B Virus Pregenomic RNA Is Present in Virions in Plasma and Is Associated With a Response to Pegylated Interferon Alfa-2a and Nucleos(t)ide Analogues. J Infect Dis. 2016; 213(2): 224-32.

38. van Bömmel F, Bartens A, Mysickova A, Hofmann J, Krüger DH, Berg T, Edelmann A. Serum hepatitis B virus RNA levels as an early predictor of hepatitis B envelope antigen seroconversion during treatment with polymerase inhibitors. Hepatology. 2015; 61(1): 66-76. 